\title{
Design and Simulation of 250kW Mini-Hydro Power
}

\author{
Cherry Soe \\ Department of Electrical \\ Power Engineering, \\ Technological University \\ Thanlyin, Myanmar
}

\author{
Myo Thet Tun \\ Department of Electrical \\ Power Engineering, \\ Technological University \\ Thanlyin, Myanmar
}

\author{
Shwe Zin Htun \\ Department of Electrical \\ Power Engineering, \\ Technological University \\ Thanlyin, Myanmar
}

\begin{abstract}
At present, electrical energy is one of the most useful forms of energy for human beings in the world. Energy in various forms is essential to sustain human life and pursue economic growth. Electrical is to sustain human life and pursue economic growth. Electrical energy can be derived from various sources of energy such as coal, diesel, nuclear, water, steam, wind, solar, heat and so on. The collected data allows for parameter optimization, suitable turbine choice and the design of generator. This paper analysis the turbine selection and generator design of mini-hydropower of Myin War Taung in Hinthada Township Ayerwaddy Division. This is done throughout design and analysis of the electrical generator aspects of the $(250 \mathrm{~kW})$ synchronous generator, which was connected to propeller turbine. Modelling and simulation of the system also described by using MATLAB software.
\end{abstract}

Keywords: Hydro location, Flow rate , Head, turbine, synchronous generator,MATLAB/Simulation

\section{INTRODUCTION}

There are various source power to produce electricity in Myanmar. Among them, water resources are suitable for Myanmar because there are many streams and rivers in Myanmar[1]. One kind of renewable energy, water is plentiful, clean and will never run out. Where water resources are available, hydro-electric power stations are used to supply electrical energy to consumers. The hydro-electric power generation is relative cheap. Moreover, it is a renewable and relatively clean power source[5]. In the other hand, most of villages in Myanmar are still living without electricity. Thus Ministry of Irrigation and Water Utilization Management Department is trying to supply electricity to nearby villages of mini-hydropower plant is presented for rural electrification. The detail study is carried out at Mamya dam, Myin War Taung in Hinthada Township Ayerwaddy Division. The calculated generator data and simulation result are also present[6].

\section{MAIN COMPONENTS OF HYDROELECTRIC POWER PLANT}

Hydroelectric Power plants convert the hydraulic potential energy from water into electrical energy. Such plants are suitable where water with suitable head is available. The different part of a hydroelectric power plant are dam,forbay,spillway,penstock and tunnel, surge tank, power house[3].

(i) Dam

The dams collect water during the rainy season and store it, thus allowing for a steady flow throughout the year. Dams are also used for controlling floods and irrigation.

(ii) Forebay
Forebay is incoming water from the head race flows into this tank at the head of the penstock. It is a storage basin in front of intake.

(iii) Spillway

A spillway as the name suggests could be called as a way for spilling of water from dams. It is used to provide for the release of flood water from a dam. It is used to prevent over toping of the dams which could result in damage or failure of dams.

(iv) Penstock and Tunnel

Penstocks are pipe which carry water from the reservoir to the turbine inside power station. They are usually made of steel and are equipped with gate systems.

(v) Surge Tank

Surge tanks are tanks connected to the water conductor system. It serves the purpose of reducing water hammering in pipes which can cause damage to pipes.

(vi) Power House

Power station contains a turbine coupled to a generator. The water brought to the power station rotates the vanes of the turbine producing torque and rotation of turbine shaft. This rotational torque is transferred to the generator and is converted into electricity[3].

\section{DESIGN THEORY FOR MINI-HYDRO POWER PLANT}

The plant is installed at the conduit, which has enough water head and flowing water flow rate to generate hydro turbine. A water control gate, penstock, control valve, turbine, generator, and related equipment are to be constructed to each unit. The flowing water from the conduits the main source of energy to convert electricity with the help of hydro turbine which connected to the generator. The generator power could be calculated as following[6].

$$
\mathrm{P}=\eta \gamma \mathrm{QH}
$$

Where, $\mathrm{P}=$ Generated Power $(\mathrm{kW})$ 


$$
\begin{aligned}
& \eta=\text { Overall efficiency of the turbine } \\
& \gamma=\text { Specific weight of water }\left(\mathrm{KN} / \mathrm{m}^{3}\right) \\
& Q=\text { Flow rate of water }\left(\mathrm{m}^{3} / \mathrm{s}\right) \\
& \mathrm{H}=\text { Head of water }(\mathrm{m})
\end{aligned}
$$

(i) As the discharge formula

$$
\begin{aligned}
& \mathrm{Q}=\mathrm{AV} \\
& \mathrm{Q}=\pi \mathrm{R}^{2} \mathrm{~V}=3.14 \times(0.3)^{2} \times 3.27=0.92 \mathrm{~m}^{3} / \mathrm{s}
\end{aligned}
$$

(ii) As the Head formula

$$
\begin{aligned}
& \text { Output }=9.81 \times \eta \times \mathrm{Q} \times \mathrm{H} \\
& \mathrm{H}=\frac{\text { output }}{9.81 \times \mathrm{Q} \times \eta}=\frac{500}{9.81 \times 0.81 \times 1.84}=34.19 \mathrm{~m}
\end{aligned}
$$

We must be chosen hydro turbine according to the Head and Flow rate.

(iii) Hydraulic Turbines

Hydraulic or water turbine are the machines which uses the energy of water (Hydro power) and convert into mechanical energy. In general a water turbine consists of a wheel called or rotor, having a number of specially designed vanes or blades or buckets. The water processing a large amount of hydraulic energy when strikes the runner, it does work on the runner and causes it to rotate, the mechanical energy so developed is supplied to the generator coupled to the runner, generates electrical energy. The selection of the best turbine for any particular hydro site depends on the site characteristics, the dominant factors being the head available and the power required. Selection also depends on the speed at which it is desired to run the generator or other device loading the turbine[7].

(iv) Types of Turbines

The classification of hydraulic turbine is based on the predominant direction of fluid flow through the runner. Turbines are also divided by their principal of operation. The se are Impulse Turbine and Reaction Turbine. In this journal, reaction turbine is commonly used at low head site[7].

Also, the turbine may be classified into high, medium or low-head machines. These are shown in the following table.

Table.1Group of Turbine

\begin{tabular}{|l|l|l|l|}
\hline $\begin{array}{l}\text { Turbine } \\
\text { runner }\end{array}$ & High-Head & $\begin{array}{l}\text { Medium- } \\
\text { Head }\end{array}$ & Low-Head \\
\hline Impulse & $\begin{array}{l}\text { Pelton } \\
\text { Turgo Multi- } \\
\text { jet Pelton }\end{array}$ & $\begin{array}{l}\text { Multi-jet } \\
\text { Pelton } \\
\text { Cross flow } \\
\text { Turgo }\end{array}$ & Cross flow \\
\hline Reaction & - & Francis & $\begin{array}{l}\text { Kaplan } \\
\text { Propeller }\end{array}$ \\
\hline
\end{tabular}

Impulse Turbines

These turbines are most efficiency for high head low flow site. A narrow water jet impulse the blades of the turbine creating momentum. A system using an impulse turbine drives the water into a pipeline[7].

Reaction Turbine

Reaction turbines have a better performance in low head and high flow sites. In reaction turbines, there are no nozzles. The efficiency of thereactiion turbines is higher than the impulse turbines, and has slower operation speed[7].
The usual range of head, flow rate and specific speeds for various types of turbine are also shown in following table[5].

Table.2 Relationship between water head and turbines

\begin{tabular}{|l|l|l|l|}
\hline $\begin{array}{l}\text { Type of } \\
\text { Turbine }\end{array}$ & $\begin{array}{l}\text { Limit Head } \\
\text { (H) }(\mathrm{m})\end{array}$ & $\begin{array}{l}\text { Flow rate } \\
\text { (Q) } \mathrm{m}^{3} / \mathrm{s}\end{array}$ & $\begin{array}{l}\text { Specific } \\
\text { speed }\end{array}$ \\
\hline $\begin{array}{l}\text { Pelton } \\
\text { turbine }\end{array}$ & 300 to 2000 & 0.2 to 3 & 4 to 70 \\
\hline $\begin{array}{l}\text { Cross } \\
\text { turbine }\end{array}$ & 10 to 100 & 0.1 to 10 & 40 to 200 \\
\hline Francis & 2.5 to 450 & 0.4 to 20 & 60 to 400 \\
\hline Kaplan & 1.5 to 70 & 0.5 to 20 & \begin{tabular}{l}
$300 \quad$ to \\
\hline
\end{tabular} \\
\hline
\end{tabular}

According to flow rate and head,we can be chone turbine from turbine selection chart as shown in following figure.1.

Selection of Turbine Chart

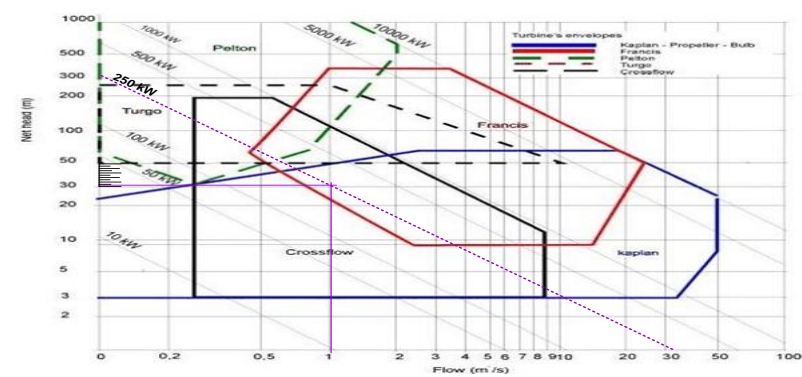

Figure.1.Turbine Selection chart according to flow rate and head

According to flow rate we can get turbine efficiency from turbine efficiency chart as shown following figure. 2 .

Selection of Turbine Efficiency

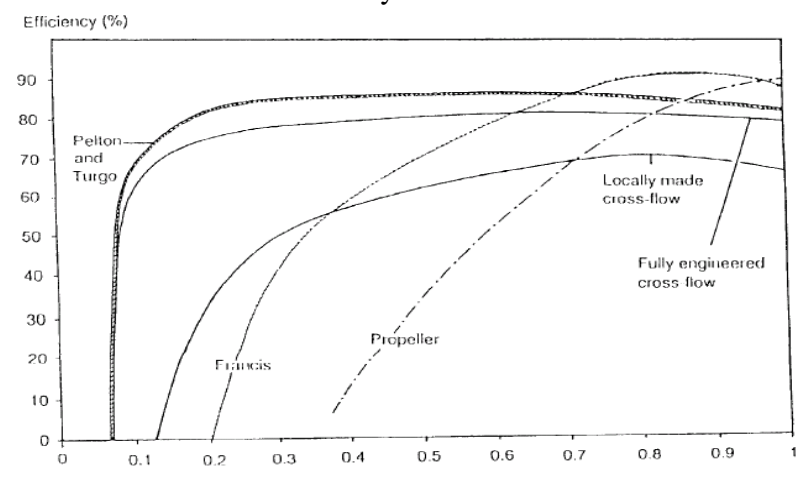

Figure.2.Turbine Efficiency according to flow rate

The required flow rate to operated turbine is $1.84 \mathrm{~m}^{3} / \mathrm{s}$ and 2 unit of Horizontal Francis type turbine was selected low head plant.But,according to analysis the various types of turbines, In this journal suitable Propeller turbine choice and design of generator. Because the Propeller turbine will rotate faster than Francis turbine. These high speed have the very important implication that reaction turbine can often be 
directly coupled to an generator without any speed increasing drive system. The Propeller turbine is suitable for low heads. The reaction turbine need more sophisticated fabrication than impulse types because these involve the use of large more intricately profiled blade[7].

\section{SYSTEM UNDER STUDY}

A Mamya Dam was constructed mainly to supply irrigation water for multiple crop cultivation. The design of mini hydro power plant by using irrigation water was created to coincide with the constructed conduit structures and the locally available materials except turbine and generator. After studying the design of conduit structure and site investigating the location for installation of hydro power plant is selected with the basic criteria such as water discharge from conduit depended on water storage and diameter; of penstock, water head depended on dam height, vicinity of villages, number of households and possibilities of power transmission line[6].

The electrification with the mini hydro power plant $(0.5$ MW) installed at the conduit outlet of Mamya Dam is the second biggest of its kind producing electricity utilized the constructed irrigation facilities for irrigation water in Myanmar. By this successful implementing of mini hydropower plant at Ma Mya Dam Project, nearby (4)villages also located near dam site with efficient water. They all get the electricity at present and have chances of creating opportunities for cottage industry development[6].

Once the mini hydro power plants are installed at the conduit outlet the power generating is available as $24 \mathrm{hrs} 335$ days a year as irrigation water is flowing continuously and another 30days are under maintenance of irrigation system.24hrusage.

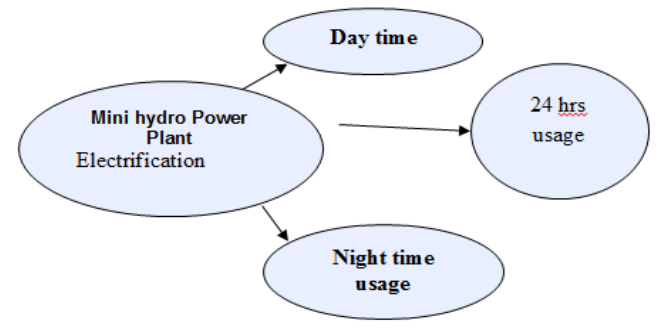

Figure.3. Daily Power Usages

\section{DESIGN CALCULATION FOR $250 \mathrm{~kW}$ SYNCHRONOUS GENERATOR}

Hydro-electric generator is the energy converter of the mechanical energy into electrical energy. Generator is classified into two main type; the synchronous generator and an induction generator[4]. This paper represents the design of a mini-hydro plant with $250 \mathrm{~kW}$ synchronous generator.

$$
\text { Outputcapacity }(\mathrm{kVA})=\frac{\mathrm{kw}-\text { rating }}{\text { powerfactor }}
$$

(i) Main Dimension of Stator Winding [2]

Output coefficient, $\mathrm{K}^{\prime}=11 \mathrm{Bav} \mathrm{q} \mathrm{kW} \times 10^{-3}$

Output of alternator, $\mathrm{Q}=\mathrm{K}^{\prime} \mathrm{D}^{2} \times \mathrm{L} \times \mathrm{n}_{\mathrm{s}}$

Number of turn per phase,

$$
\mathrm{Tph}=\frac{\mathrm{Eph}}{4.44 \times \mathrm{f} \times \varphi \times \mathrm{Kw}}
$$

$$
\mathrm{Iph}=\frac{\mathrm{kVArating}}{\text { Terminal voltage }}
$$

Outer diameter of the stator core, $\mathrm{Do}=\mathrm{D}+2 \mathrm{hs}+\mathrm{dc}$

(ii)Length of Air Gap

$$
\begin{aligned}
& \mathrm{ATa}=\frac{1.35 \times \mathrm{Tph} \times \mathrm{Iph} \times \mathrm{Kw}}{\mathrm{p}} \\
& \mathrm{AT}_{\mathrm{fo}}=\mathrm{S} . \mathrm{C} . \mathrm{R} \times \mathrm{ATa} \\
& \mathrm{ATg}=0.75 \times \mathrm{AT}_{\mathrm{fo}} \\
& \text { Rotor diameter, } \mathrm{Dr}=\mathrm{D}-2 \mathrm{Lg}
\end{aligned}
$$

(iii)Dimension of Rotor

Axial Length of the pole, $\mathrm{Lp}=\mathrm{L}-1 \mathrm{~cm}$

Width of the pole, $b p=\frac{A p}{L p}$

Height of the pole, hf $=\frac{\text { IfTf }}{10^{4} \sqrt{\mathrm{dr} \times \mathrm{Sf} \times \mathrm{Pf}}}$

\begin{tabular}{|c|c|c|c|}
\hline \\
\hline Specification & Symbol & Unit & Value \\
\hline $\begin{array}{c}\text { Full load } \\
\text { output }\end{array}$ & Q & KVA & 290.69 \\
\hline Line Voltage & $\mathrm{V}$ & Volt & 400 \\
\hline Phase & - & - & 3 \\
\hline Frequency & $\mathrm{F}$ & $\mathrm{Hz}$ & 50 \\
\hline Speed & $\mathrm{N}$ & r.p.m & 750 \\
\hline \multicolumn{4}{|c|}{ Main Dimensions } \\
\hline $\begin{array}{c}\text { Output } \\
\text { coefficient }\end{array}$ & $\mathrm{K}^{\prime}$ & - & 135.77 \\
\hline $\begin{array}{c}\text { Internal } \\
\text { diameter of } \\
\text { stator }\end{array}$ & $\mathrm{D}$ & $\mathrm{m}$ & 0.6 \\
\hline $\begin{array}{c}\text { Gross length } \\
\text { of stator }\end{array}$ & $\mathrm{L}$ & $\mathrm{m}$ & 0.471 \\
\hline $\begin{array}{c}\text { Peripheral } \\
\text { speed }\end{array}$ & V & $\mathrm{m} / \mathrm{sec}$ & 23.55 \\
\hline \multicolumn{4}{|c|}{ Stator Winding } \\
\hline
\end{tabular}

Depth of rotor core, $\mathrm{dc}=\frac{\mathrm{Ac}}{\mathrm{Lc}}$

According to above equation, design calculation of $(250 \mathrm{~kW})$ synchronous generator.This is shown in the following table.

Table.3 Design Data Sheet for 290.69 kVA Salient

Pole Alternator 
International Journal of Science and Engineering Applications

Volume 7-Issue 11,452-458, 2018, ISSN:-2319-7560

\begin{tabular}{|c|c|c|c|}
\hline $\begin{array}{c}\text { Flux per } \\
\text { phase }\end{array}$ & $\varnothing$ & $\mathrm{Wb}$ & 0.061 \\
\hline $\begin{array}{c}\text { Turn per } \\
\text { phase }\end{array}$ & $\mathrm{T}_{\mathrm{ph}}$ & - & 16 \\
\hline $\begin{array}{c}\text { Number of } \\
\text { slot }\end{array}$ & $S$ & - & 96 \\
\hline $\begin{array}{c}\text { Conductor } \\
\text { per slot }\end{array}$ & $\mathrm{Z}_{\mathrm{s}}$ & - & 1 \\
\hline $\begin{array}{c}\text { Teeth per } \\
\text { pole }\end{array}$ & $\mathrm{N}_{\mathrm{t}}$ & - & 12 \\
\hline $\begin{array}{l}\text { Conductor } \\
\text { C.S.A }\end{array}$ & $a_{\mathrm{s}}$ & $\mathrm{mm}^{2}$ & 140 \\
\hline $\begin{array}{c}\text { Size of } \\
\text { conductor }\end{array}$ & - & $\mathrm{mm} \times \mathrm{mm}$ & $10.39 \times 13.47$ \\
\hline Width of slot & $\mathrm{b}_{\mathrm{s}}$ & $\mathrm{m}$ & 0.01139 \\
\hline Depth of slot & $\mathrm{h}_{\mathrm{s}}$ & $\mathrm{m}$ & 0.01527 \\
\hline $\begin{array}{l}\text { Resistance } \\
\text { of winding }\end{array}$ & $\mathrm{R}_{\mathrm{ph}}$ & $\Omega$ & 0.004 \\
\hline $\begin{array}{l}\text { Effective } \\
\text { resistance }\end{array}$ & - & p.u & 0.009 \\
\hline $\begin{array}{l}\text { Effective } \\
\text { reactance }\end{array}$ & - & p.u & 0.3062 \\
\hline \multicolumn{4}{|c|}{ Field Winding } \\
\hline $\begin{array}{l}\text { Short circuit } \\
\text { ratio }\end{array}$ & S.C.R & - & 1 \\
\hline $\begin{array}{l}\text { Air-gap } \\
\text { length }\end{array}$ & $\mathrm{Lg}$ & $\mathrm{m}$ & $1.525 \times 10^{-3}$ \\
\hline $\begin{array}{c}\text { Arial length } \\
\text { of pole }\end{array}$ & Lp & $\mathrm{m}$ & 0.461 \\
\hline $\begin{array}{c}\text { Width of } \\
\text { pole }\end{array}$ & $b_{p}$ & $\mathrm{~m}$ & 0.116038 \\
\hline $\begin{array}{l}\text { Height of } \\
\text { pole }\end{array}$ & $\mathrm{h}_{\mathrm{p}}$ & $\mathrm{m}$ & 0.07826 \\
\hline $\begin{array}{c}\text { Total no } \\
\text { load Ampere } \\
\text { turns }\end{array}$ & AT & - & 1498.232 \\
\hline $\begin{array}{l}\text { Full load } \\
\text { field } \\
\text { Ampere } \\
\text { turns }\end{array}$ & $\mathrm{AT}_{\mathrm{fl}}$ & - & 3099.85 \\
\hline
\end{tabular}

\begin{tabular}{|c|c|c|c|}
\hline $\begin{array}{c}\text { Sectional } \\
\text { area of field } \\
\text { conductor }\end{array}$ & $\mathrm{a}_{\mathrm{f}}$ & $\mathrm{mm}^{2}$ & 27.999 \\
\hline Field current & $\mathrm{I}_{\mathrm{f}}$ & $\mathrm{A}$ & 88.19 \\
\hline $\begin{array}{c}\text { Field turn } \\
\text { per coil }\end{array}$ & $\mathrm{T}_{\mathrm{f}}$ & - & 20 \\
\hline $\begin{array}{c}\text { Resistance } \\
\text { of field } \\
\text { winding }\end{array}$ & $\mathrm{R}_{\mathrm{f}}$ & $\mathrm{a}$ & 0.01935 \\
\hline
\end{tabular}

Performance calculation of $(250 \mathrm{~kW})$ synchronous generator ass following table.

Table.4Analysis of Performance generator

Losses and efficiency.

\begin{tabular}{|l|c|c|}
\hline & Losses & W \\
\hline (a) & Stator copper losses & 3107.31 \\
\hline (b) & Iron losses & 2961.54 \\
\hline (c) & Rotor losses & 1204.52 \\
\hline (d) & Exciter losses & 164.2532 \\
\hline (e) & Fic \&windge losses & 2500 \\
\hline & Total & 10223.85 \\
\hline
\end{tabular}

Output of the alternator $\quad=290.69 \times 0.86$

$$
\begin{aligned}
\text { Input of the Alternator } & =250 \mathrm{~kW}+10.223 \mathrm{~kW} \\
\therefore \quad & \eta=\frac{250 \times 10^{3}}{250 \times 10^{3}+10.223 \times 10^{3}} \\
& =96.5 \%
\end{aligned}
$$

\section{MODELING OF THE SYSTEM}

This model incorporates the models of the synchronous generator, hydro turbine governor, excitation system and three phase RLC load are now connected together to the complete block diagram of mini-hydro power plant as shown in (figure.4). 


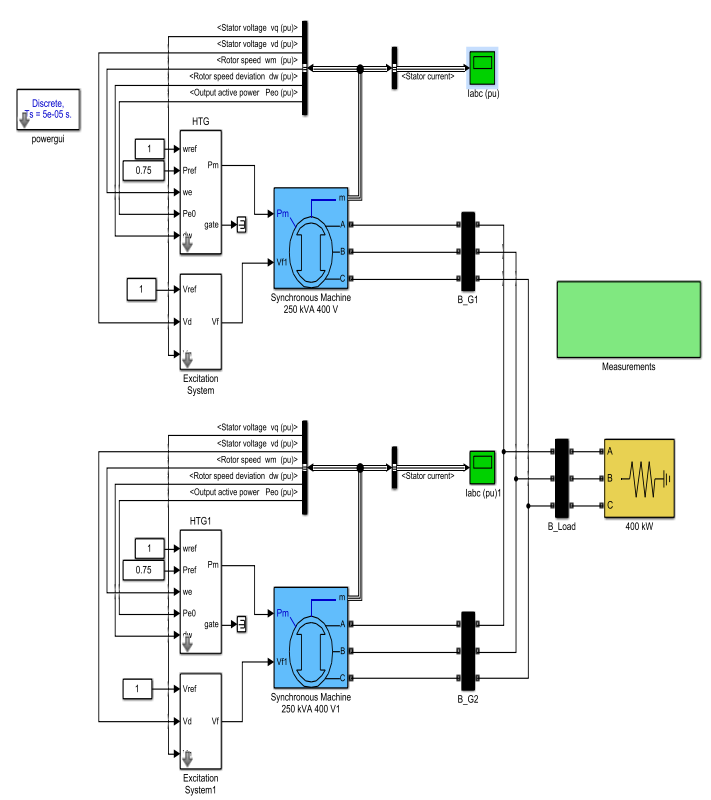

Figure 4.Simulation Model for Designed System

(i) Components of Mini-hydropower system

The main component of mini-hydropower system with synchronous generator are-

1. Hydraulic turbine

2. Excitation system

3. Synchronous generator

Measurement System in simulation model as shown in following figure(5).
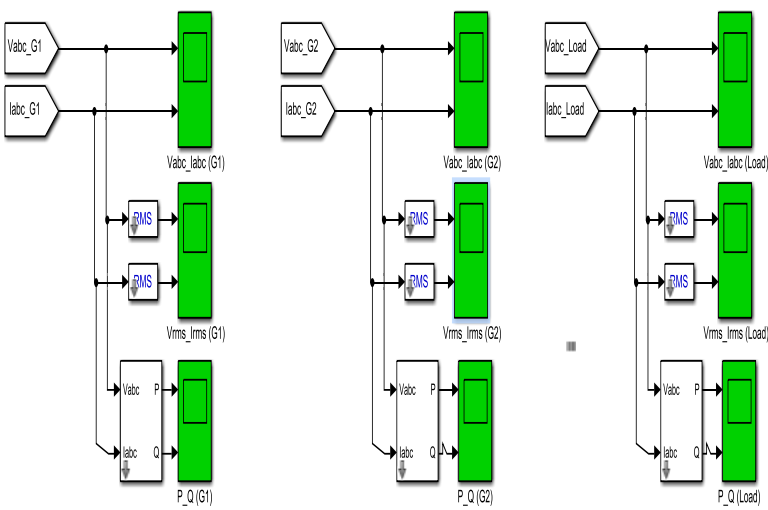

Figure.5. Measurement System in Simulation Model

\section{SIMULATION AND ANALYSIS}

At first author has to simulate the response of synchronous generator for single machine infinite bus system at normal operation. The system is simulated to study about dynamic characteristics of synchronous generator with its own transient condition. Figure 6.show the simulation results of stator current for phase $a, b$, and $c$ of generator $G_{1}$ and $G_{2}$ in mini-hydro power system.

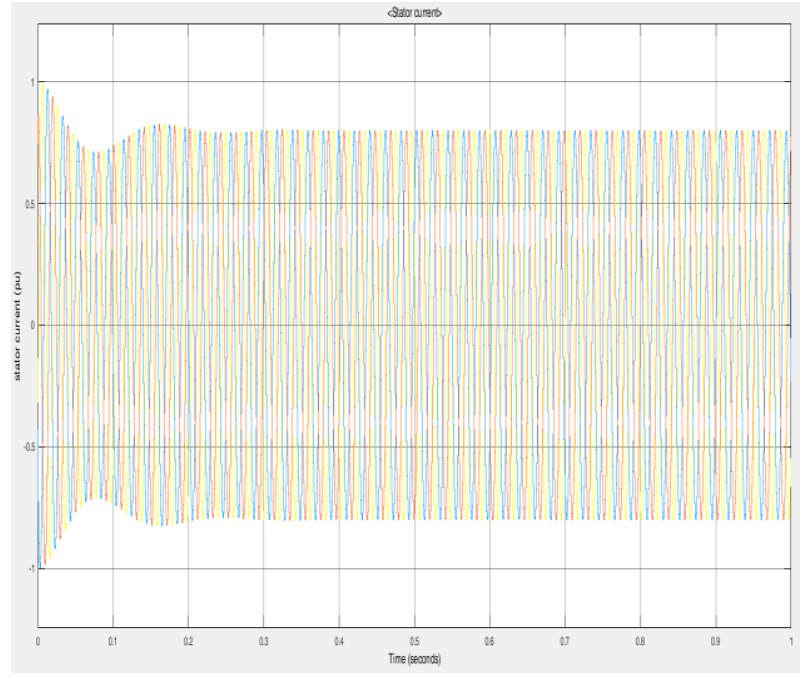

Figure 6. Simulation Results of Stator Current for Phase a, b and $c$ of Generator $G_{1}$ and $G_{2}$

(ii) Simulation Results of Generator $\left(\mathrm{G}_{1}\right.$ and $\left.\mathrm{G}_{2}\right)$

By this simulation, the transient condition of synchronous generator. In this section, the simulation result of Phase Voltage (V) and Phase currents, RMS voltage (V) and RMS currents, and Real power and Reactive power of $G_{1}$ and $\mathrm{G}_{2}$ as shown in following figure.

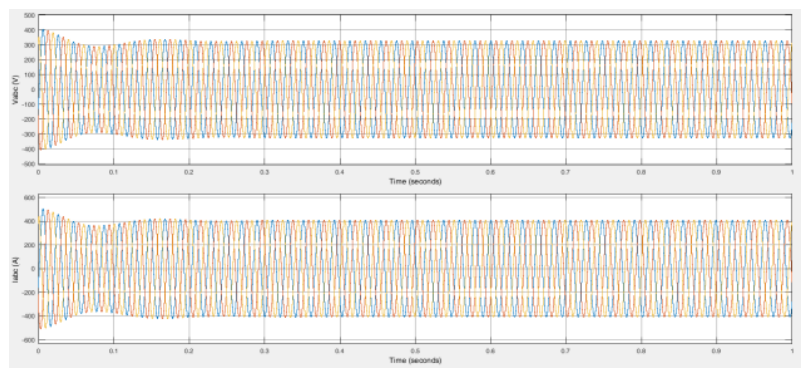

Figure7.Simulation result of Phase Voltages (V) and Phase Currents of Generator $\mathrm{G}_{1}$ and $\mathrm{G}_{2}$

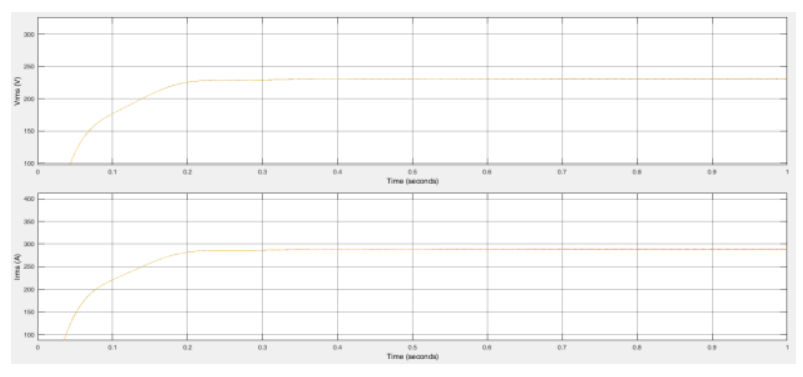

Figure.8.Simulation result of RMS voltages (V) and RMS currents of Generator $\mathrm{G}_{1}$ and $\mathrm{G}_{2}$ 


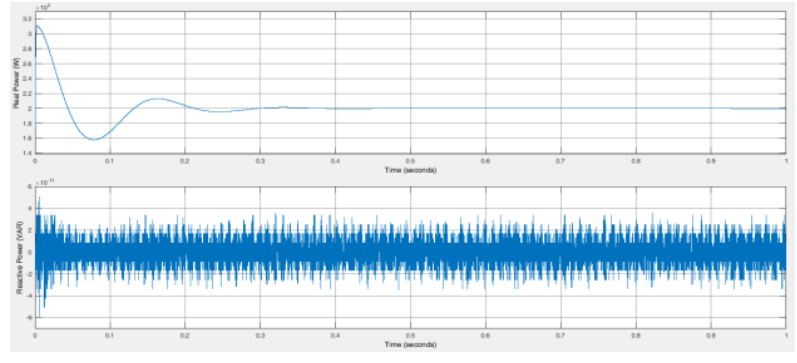

Figure.9.Simulation Result of Real Power and Reactive Power of Generator $\mathrm{G}_{1}$ and $\mathrm{G}_{2}$

(iii) Simulation Results of Load

In this section, the simulation result of the minihydropower system with synchronous generator designed $(400 \mathrm{~kW})$ for three phase load. All simulation results of minihydropower system can be seen in below figures.

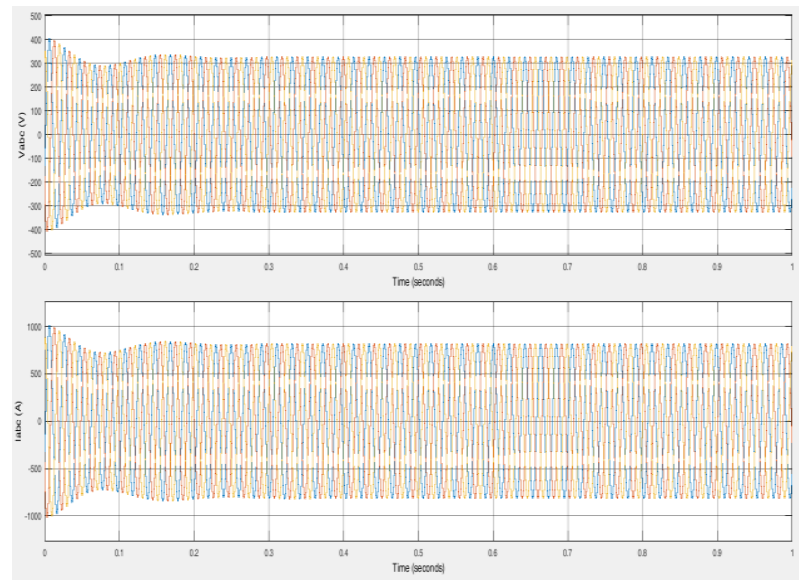

Figure10. Simulation result of Phase a,b,c voltage (V) and Phase a,b,c current of Load

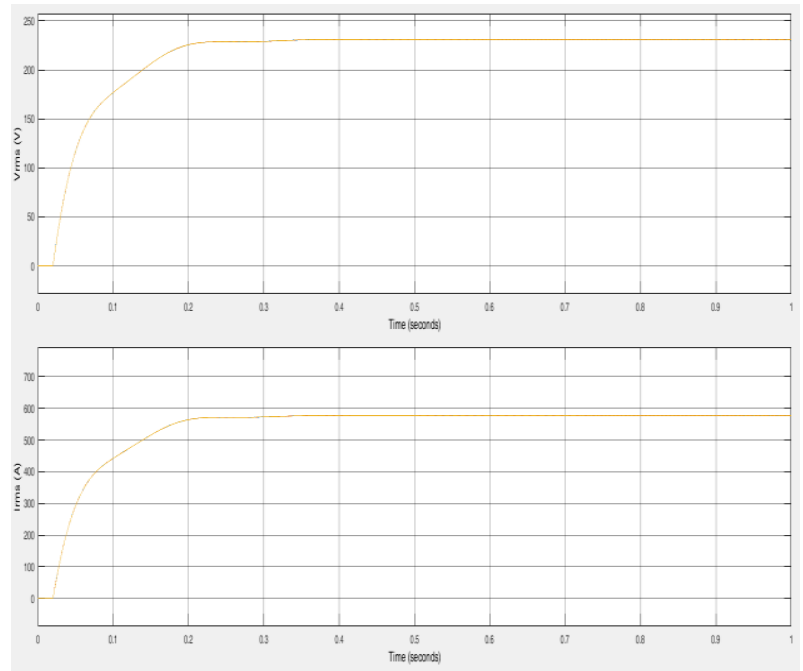

Figure.11. Simulation result of RMS voltage (V) and RMS currents of Load

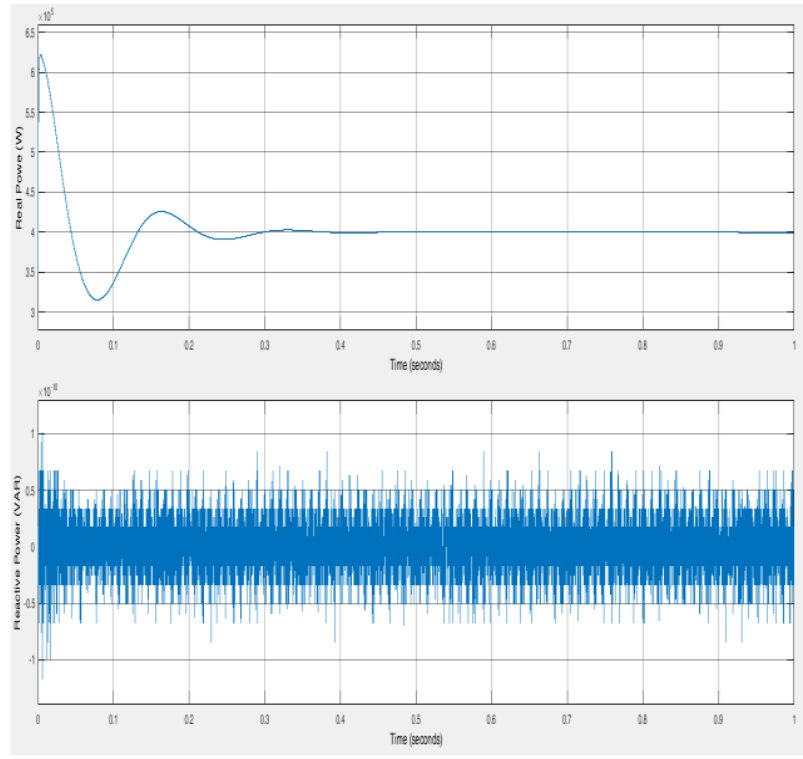

Figure112. Simulation result of Real Power (W) and Reactive Power (VAR) of Load

\section{CONCLUSION}

In this paper, detail generator design data, simulation model for designed system, simulation result and turbine selection are presented. According to selected case, condition propeller turbine is selected. The generator input is $250 \mathrm{~kW}$ and the efficiency of the generator is $96.5 \%$,it is satisfactory for $250 \mathrm{~kW}$ generator size. And then, the overall model and results of mini hydro power system are analyzed by Matlab.

\section{ACKNOWLEDGMENTS}

First of all, the author is grateful to Dr. Thein Gi, Rector of Technological University (Thanlyin), for giving the permission to submit the paper.

The author would like to than her Supervisor, Dr. Myo Thet Tun,Professor and Head of Electrical Power Engineering Department, Technological University(Tanlyin) for his kind supervision, encouragement, suggestion and valuable guidance for this paper. And then, special thanks are also owed to Cosupervisor, Daw Shwe Zin Htun,lecturer and all of teachers, Electrical Power Engineering Department, Technological University(Thanlyin).

\section{REFERENCES}

[1] Adam Harvey,"MICRO-HYDRO DESIGN MANUAL", a guide to small-scale water power schemes,by . with Andy Brown,1993 Priyantha Hettiarachi and AllenInversin.

[2] Mittle, V.N, and Mittal, A.: Design of Electrical Machines, $4^{\text {th }}$.ed.1996, Delhi: Standard Publishers Distributors.

[3] European Small Hydropower Association..How to Develop a Small Hydro Site.2000,Layman's Guidbook. 
International Journal of Science and Engineering Applications

Volume 7-Issue 11,452-458, 2018, ISSN:-2319-7560

[4] Agarwal, R.K.: Principle of Electrical Machine Design, $4^{t}$.ed. Delhi:2000, Standard Publishers Distributors.

[5] Guilherme A. Caxaria, 'Small scal hydropower: generato analysis and optimization for water supply systems',2011,Linkoping Sweden.

[6] "Minstry of Irrigation and Water Utilization Management Department'2017Hand Book.

[7] Prof.Q.H.Nagpurwala, 'Design of Hydralic Turbine 